\title{
Environmental impact assessment of coal power plants in operation
}

\author{
Ayfer Bartan ${ }^{1}$, Serhat Kucukali ${ }^{2, *}$, and Irfan $\mathrm{Ar}^{1}$ \\ ${ }^{1}$ Gazi University, Chemical Engineering Department, Maltepe, Ankara, Turkey \\ ${ }^{2}$ Cankaya University, Civil Engineering Department, 06790, Ankara, Turkey
}

\begin{abstract}
Coal power plants constitute an important component of the energy mix in many countries. However, coal power plants can cause several environmental risks such as: climate change and biodiversity loss. In this study, a tool has been proposed to calculate the environmental impact of a coal-fired thermal power plant in operation by using multicriteria scoring and fuzzy logic method. We take into account the following environmental parameters in our tool: $\mathrm{CO}, \mathrm{SO}_{2}, \mathrm{NO}_{\mathrm{x}}$, particulate matter, fly ash, bottom ash, the cooling water intake impact on aquatic biota, and the thermal pollution. In the proposed tool, the boundaries of the fuzzy logic membership functions were established taking into account the threshold values of the environmental parameters which were defined in the environmental legislation. Scoring of these environmental parameters were done with the statistical analysis of the environmental monitoring data of the power plant and by using the documented evidences that were obtained during the site visits. The proposed method estimates each environmental impact factor level separately and then aggregates them by calculating the Environmental Impact Score (EIS). The proposed method uses environmental monitoring data and documented evidence instead of using simulation models. The proposed method has been applied to the 4 coal-fired power plants that have been operation in Turkey. The Environmental Impact Score was obtained for each power plant and their environmental performances were compared. It is expected that those environmental impact assessments will contribute to the decision-making process for environmental investments to those plants. The main advantage of the proposed method is its flexibility and ease of use.
\end{abstract}

\section{Introduction}

Measures for environmental control in modern coal-fired thermal power plants may be useful in reducing $\mathrm{SO}_{2}, \mathrm{NOx}$, and particulate matter emissions. It has become important to calculate the environmental impacts of such power plants with the cumulative impact assessment, which has also taken place at the legal level. Coal-fired thermal power plants have been subject to many studies because of their high environmental impact. When studies in the literature are evaluated, it is concluded that the following gaps are identified:

\footnotetext{
*Corresponding author: kucukali@cankaya.edu.tr
} 
existence of deeper studies mostly on more specific issues, (ii) lack of studies to evaluate environmental parameters as a whole, (iii) lack of studies on the development of cumulative environmental impact analysis [1]. Moreover, previous studies aimed to calculate the environmental impact index of coal-fired thermal power plant at the planning stage [1]. However, this study focused on calculating the environmental impact index of a thermal power plant in operation. A new tool has been proposed to calculate the environmental impact index, which is used in combination with fuzzy logic membership functions and multi-criteria scoring technique. This study evaluates the environmentally monitored parameters of a coal-fired thermal power plant in operation.

\section{Environmental impact index parameters membership functions}

Environmental parameters imposed by the relevant Regulations for monitoring in thermal power plants in Turkey are given in Table 1.

Table 1. Environmental parameters related to coal-fired thermal power plants in operation.

\begin{tabular}{|c|c|c|c|}
\hline $\begin{array}{c}\text { Name of } \\
\text { Monitored } \\
\text { Parameters } \\
\end{array}$ & $\begin{array}{c}\text { Monitored } \\
\text { Parameter Unit }\end{array}$ & & Regulation \\
\hline \multirow{4}{*}{ Emissions } & $\mathrm{SO}_{\mathrm{x}}$ & $\mathrm{mg} / \mathrm{Nm}^{3}$ & Regulation on Control of Industrial Air Pollution \\
\hline & $\mathrm{NO}_{\mathrm{x}}$ & $\mathrm{mg} / \mathrm{Nm}^{3}$ & Regulation on Control of Industrial Air Pollution \\
\hline & $\mathrm{CO}$ & $\mathrm{mg} / \mathrm{Nm}^{3}$ & $\begin{array}{c}\text { Regulation on Control of Industrial Air Pollution } \\
\text { Implementing Regulation on Greenhouse Gas } \\
\text { Emissions }\end{array}$ \\
\hline & $\begin{array}{c}\text { Particulate } \\
\text { Matter }\end{array}$ & $\mathrm{mg} / \mathrm{Nm}^{3}$ & Regulation on Control of Industrial Air Pollution \\
\hline $\begin{array}{c}\text { Water } \\
\text { Temperature }\end{array}$ & Temperature & ${ }^{0} \mathrm{C}$ & Water Pollution Control Regulation \\
\hline $\begin{array}{c}\text { Waste } \\
\text { Management }\end{array}$ & $\begin{array}{l}\text { Fly Ash and } \\
\text { Bottom Ash }\end{array}$ & $\begin{array}{l}\mathrm{Kg} / \\
\text { year }\end{array}$ & $\begin{array}{c}\text { Regulation on the Regular Storage of Wastes } \\
\text { Environmental Impact Assessment Regulation } \\
\text { Waste Management Regulation } \\
\text { Notice on recycling of Some Non-dangerous } \\
\text { wastes }\end{array}$ \\
\hline
\end{tabular}

In this study, environmental parameters were selected which were continuously monitored in thermal power which are required by the legislation. However, some parameters have been left out of the assessment because they are not actively monitored by the responsible government agency. In summary; In Turkey, eight important environmental parameters that can be assessed consistently in thermal power plants or objectively evaluated by documented evidence have been evaluated. These are: $\mathrm{SO}_{2}, \mathrm{NOx}, \mathrm{CO}$, particulate matter (dust), water temperature $\left(T_{w}\right)$, fly ash, bottom ash, water intake for cooling water (Fish Friendly Pump). In the environmental legislation $\mathrm{CO}$ emission allowable value is defined as $200 \mathrm{mg} / \mathrm{Nm}^{3}$ (Fig. 1); while the limit value for $\mathrm{NO}_{\mathrm{x}}$ emissions is $600 \mathrm{mg} / \mathrm{Nm}^{3}$ for coal-fired power plants (Fig. 2). 


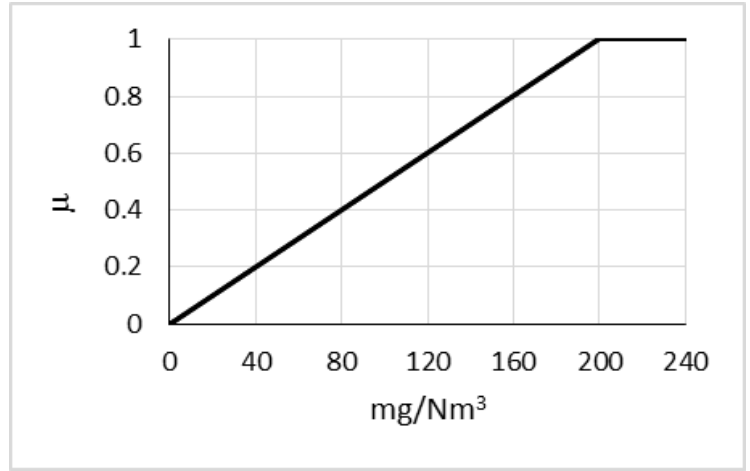

Fig. 1. Environmental impact score membership function of $\mathrm{CO}$ emissions.

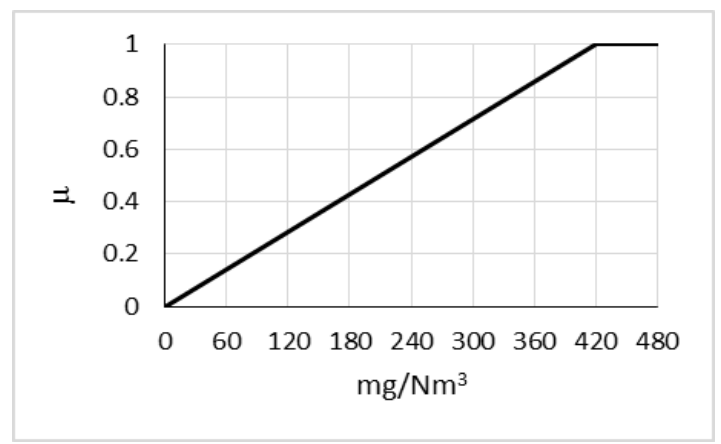

Fig. 2. Environmental impact score membership function of NOx emission.

The $\mathrm{SO}_{2}$ emissions are set at a limit value based on the fuel thermal power and the installed power of the Cates thermal power plant is stated as $314 \mathrm{MW}$. According to this, in the legislation the limit value is defined as linear decrease as $2000-400 \mathrm{mg} / \mathrm{Nm}^{3}$. The environmental impact value when exceeding the specified threshold value shall be considered as 1 (one) if it does not exceed 0 (zero).

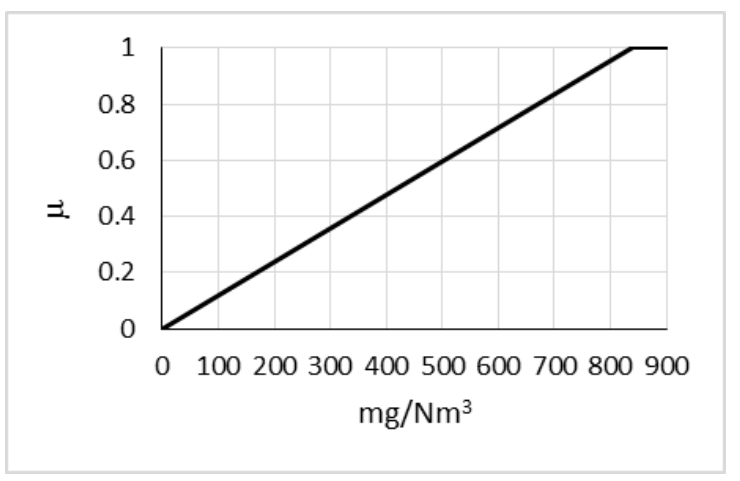

Fig. 3. $\mathrm{SO}_{2}$ emissions environmental impact score membership function. 
Dust emissions are not dependent on fuel heat power, but for all plants the threshold value is defined as $100 \mathrm{mg} / \mathrm{Nm}^{3}$ in the legislation (Fig. 4).

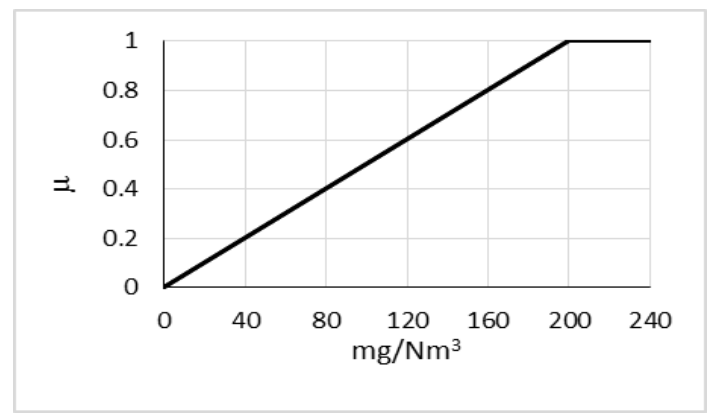

Fig. 4. Environmental impact score membership function of particulate matter.

It was stated that, regardless of the dilution capacity of the marine environment, the temperature of the waters to be discharged to the sea would not exceed the limit value of $35^{\circ} \mathrm{C}$ in the legislation (Fig. 5). Accordingly, the limit value was chosen as $35^{\circ} \mathrm{C}$ by taking environmental legislation as expert judgment.

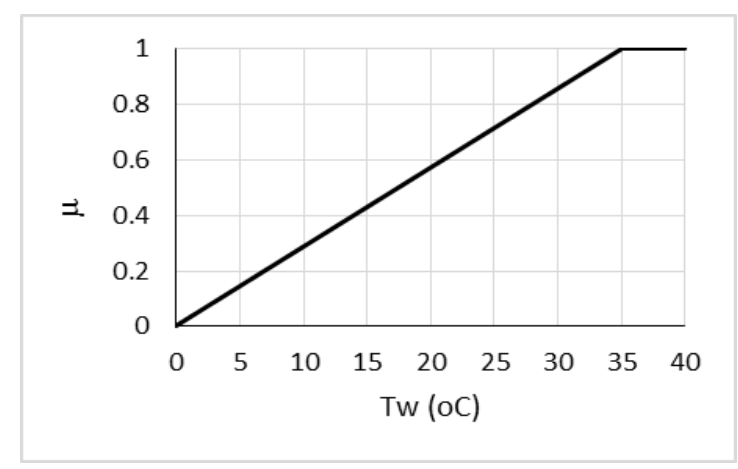

Fig. 5. Environmental impact score membership function of discharged water temperature.

For bottom ash, on evidence basis, membership functions are defined in Fig. 6.

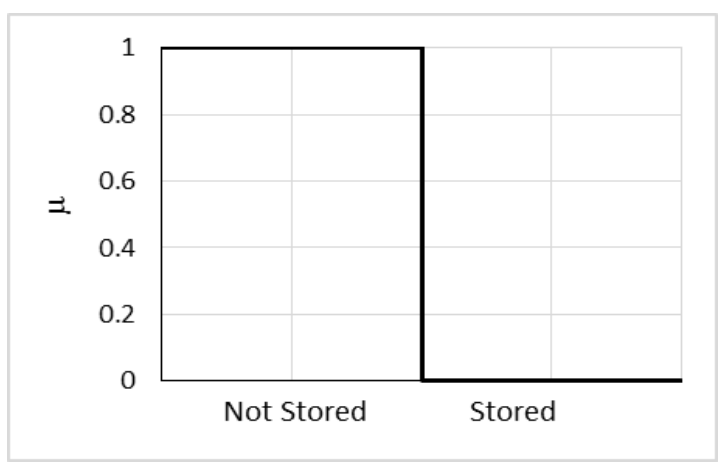

Fig. 6. Bottom ash environmental impact scoring membership function. 
The thermal power plant is being sold for use in fly ash concrete industry. Fly ash is considered to be environmentally beneficial because it is not left as waste and forms the input part of different industries as recycling (GD). For this reason, as the membership function is sold, the impact score is evaluated as zero (0). Otherwise it will be taken as one (Fig. 7).

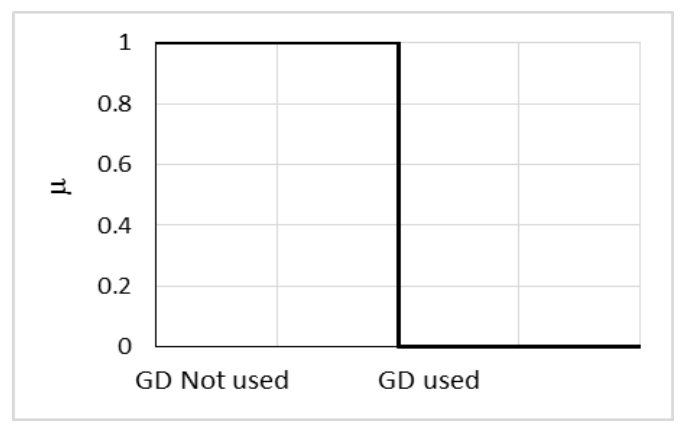

Fig. 7. Fly ash environmental impact scoring membership function.

When the water intake structure is evaluated, it is emphasized that fish friendly water intake should be used. Since the use of fish-friendly pump was not considered at this point, the impact score was evaluated as 1 because the water intake structure had a negative effect on aquatic organisms (Fig. 8).

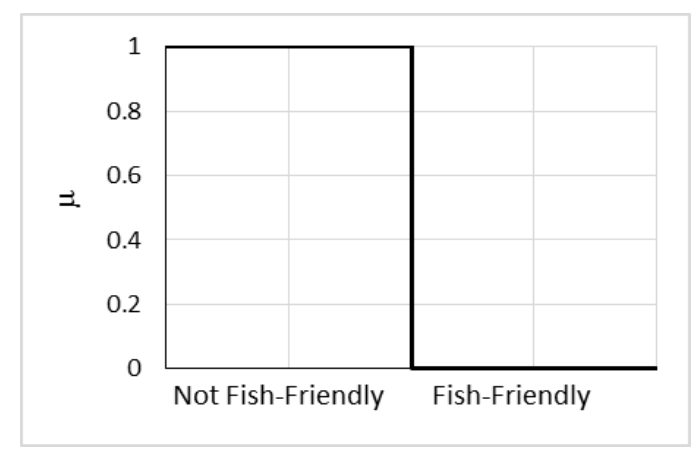

Fig. 8. Environmental impact score membership function of fish-friendly water intake.

\section{Calculation of the environmental impact index}

Previous studies in the literature aimed to calculate the environmental impact index of the coal-fired thermal power plant at the planning stage. In addition, studies on the environmental impact of a coal-fired thermal power plant operating in the literature have focused on a single environmental parameter, neglecting the cumulative effect. In this study, it was focused on calculating the environmental impact index of a thermal power plant in operation. In the calculation of the Environmental Impact Index; measured data, documented evidence (i.e. drawings, contracts), and site visits were taken as basis. A similar method has been previously developed by Kucukali [2] for the calculation of the Environmental Risk Index of river type hydroelectric power plants in operation, adapted to Coal-fired thermal plants. However, Kucukali [2] did not use the fuzzy logic membership 
functions in his work. In the establishment of fuzzy logic membership functions, Ak et al. [3] method has been employed. The threshold values determined by the legislation in the establishment of the limit values of the fuzzy logic membership functions. Multi-criteria scoring technique was used in the proposed method. Here, a Plant Environmental Impact Index (EII) value is calculated from the following formula:

$$
C S I=w_{1} \times S_{1}+w_{2} \times S_{2}+\ldots w_{n} \times S_{n}
$$

in which, $w_{l}$ is the weight ratio of the related parameter, $S_{l}$ is the score of the corresponding parameter calculated from the fuzzy logic function, and $\mathrm{n}$ is the number of environmental parameters. In this study, 8 environmental parameters were used and all parameters were given equal weight. The EII varies from 0 to 1 and the high value of the EII indicates that the plant has a high environmental impact. The value of the EII of a plant is calculated on a monthly basis, depending on the change in operating and working conditions. One of the most important parts of the proposed method is that the measured environmental parameters are transformed into a dimensionless common measure at $0-1$ interval.

\section{Application of the proposed tool to the thermal power plants in turkey}

The proposed method is based on 4 thermal power plants in Turkey. The locations of these thermal power plants in Turkey is shown on map in Fig. 9 and the technical characteristics of those power plants are presented in Table 2.

Table 2. Characteristics of the coal-fired thermal power plants for which the Environmental Impact Index is calculated in the scope of the study.

\begin{tabular}{|c|c|c|c|}
\hline Power Plant Name & In Operation since & Installed Power (MW) & Cooling Water \\
\hline Tunçbilek, Kütahya & 1956 & 365 & Cooling tower \\
\hline Yeniköy, Muğla & 1986 & 420 & Cooling tower \\
\hline Yeniköy, Muğla & 1993 & 630 & Aegean Sea \\
\hline Soma(B), Manisa & 1981 & 990 & Cooling tower \\
\hline
\end{tabular}

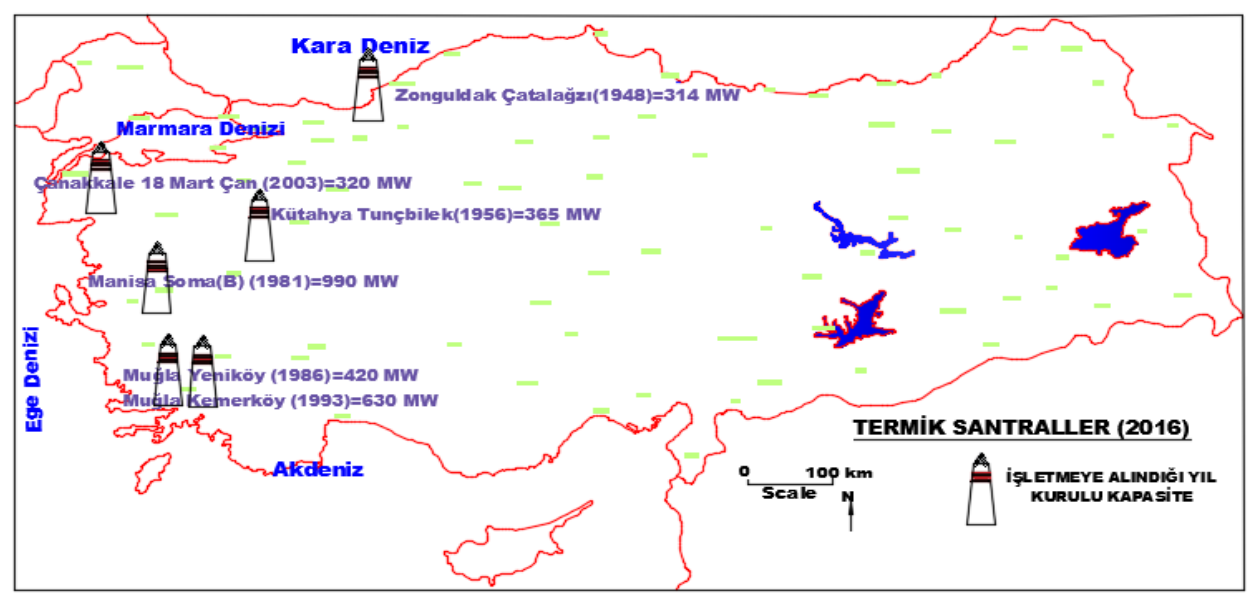

Fig. 9. Locations of the Thermal Power Plants in Turkey, for which Environmental Impact Indexes are calculated within the scope of the study. 
The calculation of the Environmental Impact Index takes into account the gases emitted $\left(\mathrm{CO}, \mathrm{SO}_{2}, \mathrm{NO}_{\mathrm{X}}\right)$, the effect of the water intake on aquatic life, the discharge cooling water temperature, the fly ash, and the bottom ash parameters. The hours the plant does not work are not taken into account. The values between 01.10.2014 and 31.10.2014 are taken into account for all power plants. Thus, each of the 8 identified environmental impact parameters were examined separately. Percentage of observed values per hour in the environmental parameters scored at $5 \%$ of the time (Fig. 10) and other parameters were scored according to documented evidence. In addition, it is necessary to make a site visit to the plant where the environmental performance is measured and to observe the examined environmental parameters in the proposed method. Then, the Environmental Impact Index of each plant was obtained by adding up the cumulative effect of these parameters. In the evaluation 0-1 interval, environmental impact index was calculated by fuzzy logic application according to membership status. If the Environmental Impact Index is close to 0 , it will be considered as a fully environmentally friendly plant. As far as the result goes from 0 to 1 , the environmental impact will be considered as a high facility. The Environmental Impact Index for four more coal-fired thermal power plants was found. The results are given in Table 3.

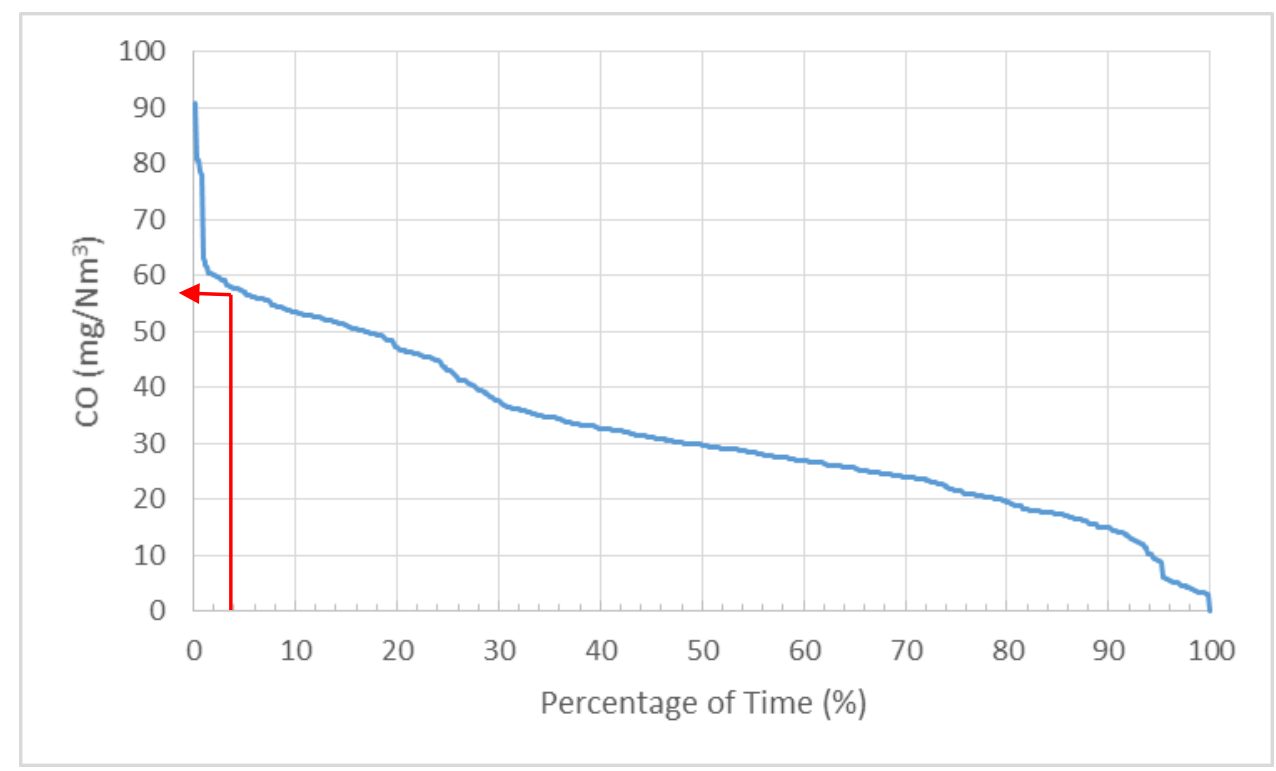

Fig. 10. CO emission duration curve for Kemerköy coal fired thermal power plant and the $5 \%$ value. The corresponding fuzzy membership value is read from Fig. 1 as 0.28 . (Sampling period: 01/10/2014-31/10/2014 for hourly-averaged values). 
Table 3. Environmental impact scores of the studied thermal power plants in operation (monthly evaluation between 01/10/2014-31/10/2014).

\begin{tabular}{|c|c|c|c|c|c|c|c|c|c|}
\hline $\begin{array}{c}\text { Coal Fired } \\
\text { Thermal } \\
\text { Power Plant }\end{array}$ & CO & NOx & SO $_{\mathbf{2}}$ & $\begin{array}{c}\text { Particulate } \\
\text { matter }\end{array}$ & $\mathbf{T}_{\mathbf{w}}$ & $\begin{array}{c}\text { Fish } \\
\text { Friendly } \\
\text { Pump }\end{array}$ & $\begin{array}{c}\text { Fly } \\
\text { Ash }\end{array}$ & $\begin{array}{c}\text { Bottom } \\
\text { Ash }\end{array}$ & $\begin{array}{c}\text { Environmental } \\
\text { Impact } \\
\text { Index }\end{array}$ \\
\hline Kemerköy & 0.28 & 0.91 & 1 & 0.89 & 0.82 & 0 & 1 & 0 & 0.61 \\
\hline Yeniköy & 0.05 & 0.91 & 1 & 0.94 & 0 & 0 & 1 & 0 & 0.49 \\
\hline Tunçbilek & 0.07 & 1 & 1 & 1 & 0 & 1 & 0 & 0 & 0.52 \\
\hline Soma & 0.15 & 0.78 & 1 & 1 & 0 & 0 & 1 & 0 & 0.48 \\
\hline
\end{tabular}

\section{Conclusions}

For the environmental impact assessment of coal-fired power plant a composite model, which is a combination of statistical analysis and fuzzy logic method, is developed. Thus, proposed tool considers the environmental legislation as an expert in order to determine the boundaries of fuzzy membership functions. The advantage of this method is flexibility and ease of use. But, the proposed method have some limitations. It can be used only during the operation phase and it requires environmental monitoring data of power plant. Therefore, the data availability and collection could represent a limitation. The proposed method has been applied to several coal-fired power plants in Turkey and Environmental Impact Index has been calculated for these power plants. It is expected that the proposed tool will contribute to determine the environmental performance of the thermal power plants in operation. Also the tool can be used in the decision-making process related to environmentally related investments. The results if the case studies demonstrated that the proposed tool can easily be used by the professionals to estimate the environmental impact of a coal power plant in the operation phase.

\section{References}

1. A. Bartan, PhD Thesis, Gazi University (2017)

2. S. Kucukali, Energy Sustain. Dev. 19 (2014)

3. M. Ak, E. Kentel, S. Kucukali, Renew. Sust Energ. Rev. 68 (2017) 